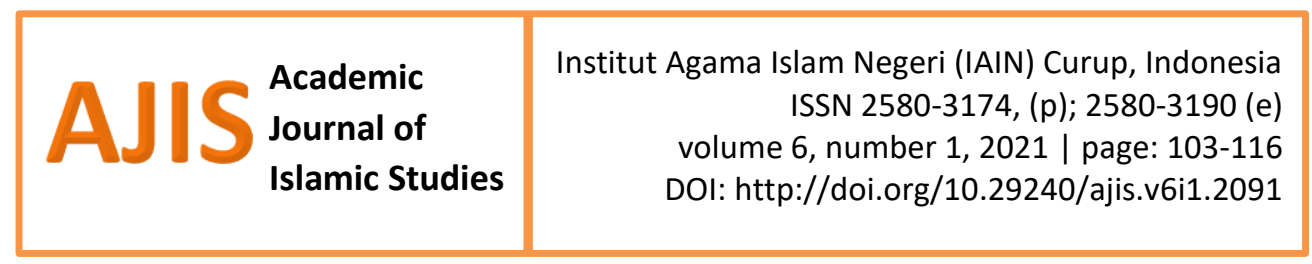

\title{
Al-Ghazali's Thoughts on Education and Its Relevance to Islamic Education in the Millennial Era
}

\author{
Guntur Gunawan, Ayunia Lestari \\ Institut Agama Islam Negeri (IAIN) Curup, Indoneisa \\ gunturgunawan@iaincurup.ac.id,ayunialestari@iaincurup.ac.id
}

\begin{abstract}
This article aims to describe and critically analyze the thoughts of Islamic education according to al-Ghazali, especially regarding the objectives, sources, methods, and curriculum and their relevance to the world of Islamic education in the millennial era. This research uses library research method, with character thinking approach. This study found that; First, al-Ghazali's thoughts on Islamic education are (a) the Qur'an and Hadith are the main foundations of education; (b) getting closer to Allah is the main intention of educators, then acting as an example for their students, and being competent in teaching; (c) the students must stay away from immorality, respect teachers and study diligently by exploring the lessons given by the teacher; (d) the curriculum as an educational tool must be adapted to the development of students; (e) students must be kept away from bad associations, because a bad environment will affect the development of the students, especially in the family, school or community environment. Second, al-Ghazali's thought has relevance to Islamic education in this millennial era, when viewed from the compatibility between al-Ghazali's educational theory and things that have been applied in the world of education..
\end{abstract}

Keywords: Al-Ghazali, Islamic Education, Millennial Era

\section{Introduction}

Education is a conscious effort made by a certain individual/group through teaching or training activities, which take place throughout life in various learning environments in order to prepare humans to play their roles appropriately. ${ }^{1}$ The elements that must exist in education are: educators, students, educational goals, educative and interactive, educational materials, educational methods and educational environment. Thus, in essence, education is an effort to humanize humans and shape human culture, so that they can create,

${ }^{1}$ Umar Tirtarahardja and La Sulo, Pengantar Pendidikan (Jakarta: PT Rineka Cipta, 2005), 1. 
work, be virtuous for life and the environment. ${ }^{2}$ Therefore, from those various definitions of education, it can be concluded that education in general can be interpreted as a planned and conscious effort to gain knowledge by following various existing educational systems.

According to al-Ghazali, education is aimed at moral and religious goals, with a focus on virtue and taqorrub to Allah and getting closer to Allah. The Islamic education expected by Imam al-Ghazali is to instill noble character in students. The requirement for educators according to Al-Ghazali is to have a pedigree of guidance or teaching up to the chiefs of the Prophet Muhammad SAW, thus educators must have several personalities that are very much needed in terms of education, such as having responsibilities in the book "Ihya' Ulumuddin", having sincere intentions and stay away from immorality, possesing an ability to distance themselves from self-indulgence worldly pleasures, having a humble nature, not giving up in seeking knowledge, staying away from negative actions, prioritizing the knowledge of the hereafter, being able to perfect knowledge in totality, having good morals, having goals or motivation to learn and knowing the glory of science. ${ }^{3}$

Islam views that children are a mandate given by Allah to their parents. They come without being asked, and have a world of their own. They are the future generation. So great is Islam to place children as candidates for the caliphate of the earth's prosperity. The future of the earth is on their shoulders, so it is no wonder that children's education is an absolute in an effort to guide and direct as well as equip them.

Al-Ghazali views that children are a mandate for their parents. They are clean like a pearl; the lines and patterns in them will color them. If it is good, the form of the painting will be good and if it is bad, the character and temperament will be bad.

With all the educational concepts that are expected by Imam AlGhazali for educational goals that are in accordance with the current era, it will be closely related to the basis of the Islamic religion because, in essence, education must be based on the Qur'an which is a guide from Allah SWT, which was revealed to His Prophet to be conveyed to all Muslims, so that all Muslims have a personality according to the teachings of Islam through His prophet. This is in line with what D. Marimba said that Islamic education is a spiritual and physical guidance

2Nanang Purwinto, Pengantar Pendidikan (Yogyakarta: Graha Ilmu, 2014), 17.

${ }^{3}$ Nu'tih Kamalia, "Konsep Ilmu Pendidikan Menurut Imam Al-Ghazali," AtTa'dib 10, no. 1 (January 26, 2016), doi:10.21111/at-tadib.v10i1.335. 
based on Islamic law in order to form a personality according to Islamic law. ${ }^{4}$

In this modern era or what is called the millennial era, there are many scientific developments which are very advanced along with the times.. There is no doubt that nowadays there are more and more things that can make people intelligent with the development of general science, technological knowledge, and scientific work, but the number of intelligent human resources with all the developments of science without being balanced by akhlaq al-karimah will also increase crimes. ${ }^{5}$

The word Millennial comes from English, namely Millennium or Millennia which means the period of a thousand years. Millennia is a term for a period that occurs after the Global era or the Modern Era. This era is interpreted by some experts as the era of back to moral and spiritual or back to religion; That is the time to return to spiritual, moral and religious based teachings.

Indonesia is a country that adheres to a system of religious understanding. Religious education has received great attention. Religious education is provided in schools ranging from elementary schools to universities. At home, in the community and at school, it is strongly recommended that religious education is carried out in an integrated and mutually supportive manner so that religion truly colors every aspect of life. Religious education, in this case Islam, especially for children, has shown significant progress with the growth and development of Islamic Kindergartens and TPA/TPQ (PAUD) in various parts of the country. Awareness to maintain and instill religious values in children seems to be very large so that the number of illiteracy of Qur'an from year to year can be eroded and reduced. ${ }^{6}$

However, the above phenomenon can be used as a benchmark to see whether education in children in this millennial era is developing or not, as we know that the purpose of education according to Article 3 of Law No. 20 of 2003 in the National Education system states:

"That national education functions to develop capabilities and shape the character and civilization of a dignified nation

${ }^{4}$ H. M. Asyari, Konsep Pendidikan Islam Implementasinya Dalam Tradisi Klasik Dan Propogasi Modern (Jakarta: Rabbani Press, 2011), iv.

5 Kamalia, "Konsep Ilmu Pendidikan Menurut Imam Al-Ghazali."

${ }^{6} \mathrm{M}$. Miftahul Ulum, "Konsep Pendidikan Anak Menurut Al-Ghazali dan Relevansinya dengan Arah dan Tujuan Pendikan Nasional di Indonesia," At-Ta'dib 4, no. 2 (September 1, 2009), doi:10.21111/at-tadib.v4i2.592. 
in the context of educating the nation's life, aiming at developing the potential of students to become human beings who believe and are devoted to God Almighty, have noble character, are creative, knowledgeable, healthy, capable, independent., and become a democratic and responsible citizen" ${ }^{\prime 7}$

Observing the contents of the law above, it is stated in the law that the purpose of national education in Indonesia is to make Indonesian people become complete human beings as the key words are faith and piety.

It seems that the condition of children's education in Indonesia today is still very far from what is expected. Especially with the various problems in the world of children's education today, which of course cannot be separated from the situation and condition of the Indonesian nation which is still slumped in a political, economic, social and cultural crisis. $^{8}$

Based on the above background, it is necessary to improve education by examining Al-Ghazali's thoughts on education and its relevance to Islamic education for children in the millennial era by looking at the notion of education, educational goals, sources of Islamic education, methods of Islamic education for children, educational curriculum according to Al-Ghazali's concept of thought, and education in the current millennial era.

Research on Al-Ghazali's thoughts on Islamic education has been carried out by several experts. Most researchers explored the educational thoughts of Al-Ghazali's perspective, including Imroh Atul Musfiroh $^{9}$, Mukronim ${ }^{10}$, Alwizar ${ }^{11}$, Syahraini Tambak ${ }^{12}$, dan Alwan

7Flavianus Darman, Undang-Undang Republik Indonesia Nomor 20 Tahun 2003 Tentang Sistem Pendidikan Nasional (Jakarta: Transmedia Pustaka, 2007), 45.

8 Ulum, "Konsep Pendidikan Anak Menurut Al-Ghazali dan Relevansinya dengan Arah dan Tujuan Pendikan Nasional di Indonesia."

9Imroh Atul Musfioh, "Pemikiran Pendidikan Islam Perspektif al-Ghazali," SYAMIL: Jurnal Pendidikan Agama Islam (Journal of Islamic Education) 2, no. 1 (June 1, 2014): 14, doi:10.21093/sy.v2i1.493.

10 Mukromin, "Pemikiran Imam Al-Ghazali Dalam Pendidikan Islam," PARAMUROBI: JURNAL PENDIDIKAN AGAMA ISLAM 2, no. 1 (October 5, 2019): 33-42, doi:10.32699/paramurobi.v2i1.814.

11 Alwizar, "Pemikiran Pendidikan Al-Ghazali," POTENSIA: Jurnal Kependidikan Islam 1, no. 1 (June 2, 2015): 129-49, doi:10.24014/potensia.v1i1.1245.

12 Syahraini Tambak, "Pemikiran Pendidikan Al-Ghazali," Al-Hikmah: Jurnal Agama Dan Ilmu Pengetahuan 8, no. 1 (2011): 73-87. 
Suban $^{13}$. These studies describe Al-Ghazali's thoughts alone without looking deeper into their relevance to educational practice.

The research conducted by Enok Rohayati ${ }^{14}$ dan La Adu ${ }^{15}$ is slightly different. They discussed moral education in Al-Ghazali's perspective. In this study, it was stated that the main goal of Islamic education according to Al-Ghazali is the moral development of students. Meanwhile, Jajang Aisyul Muzakki ${ }^{16}$ researched about Al-Ghazali's Thoughts on Rewards and Punishments in Islamic Education, and found that according to al-Ghazali, the form of reward includes three things, namely: appreciation, compliments and prizes; while regarding punishment, al-Ghazali did not agree with giving direct punishment to students, but with a gradual and careful process; Rewards and punishments in education can be used as extrinsic motivational tools for children's learning.

Miya Rahmawati ${ }^{17}$ proposed research on the application of $\mathrm{Al}-$ Ghazali's thoughts on education in early childhood. According to her, AlGhazali recommends the use of varied methods that must be adapted to the stage of development of the child's mind, such as memorization, understanding, habituation, and practice.

A rather specific study on the relevance of Al-Ghazali's educational thoughts to the education system is proposed by Adi Fadli ${ }^{18}$, especially in the education system in Indonesia. According to him, the concept of education initiated by Imam Al-Ghazali is very relevant to the education system in Indonesia in terms of educational objectives, the

13 Alwan Suban, "Konsep Pendidikan Islam Perspektif Al-Ghazali," Idaarah: Jurnal Manajemen Pendidikan 4, no. 1 (June 21, 2020): 87-99, doi:10.24252/idaarah.v4i1.13760.

${ }^{14}$ Enok Rohayati, "Pemikiran Al-Ghazali Tentang Pendidikan Akhlak," Ta'dib: Jurnal Pendidikan Islam 16, no. 01 (2011): 93-112, doi:10.19109/td.v16i01.56.

15 La Adu, "Pandangan Imam Al-Ghazali Tentang Pendidikan Akhlak Di Lingkungan Keluarga," Horizon Pendidikan 10, no. 2 (January 9, 2019), https://www.jurnal.iainambon.ac.id/index.php/hp/article/view/707.

16 Jajang Aisyul Muzakki, "Pemikiran Al-Ghazali Tentang Ganjaran Dan Hukuman Dalam Pendidikan Islam," AWLADY: Jurnal Pendidikan Anak 3, no. 1 (February 28, 2017), doi:10.24235/awlady.v3i1.1253.

17 Miya Rahmawati, "Mendidik Anak Usia Dini Dengan Berlandaskan Pemikiran Tokoh Islam Al-Ghazali," Al Fitrah: Journal of Early Childhood Islamic Education 2, no. 2 (January 1, 2019): 274-86, doi:10.29300/alfitrah.v2i2.2271.

18 Adi Fadli, "Konsep Pendidikan Imam Al-Ghazali Dan Relevansinya Dalam Sistem Pendidikan Di Indonesia," El-Hikam 10, no. 2 (2017): 276-99. 
concept of educators and students, learning methods, and the curriculum currently applied, especially character education.

These studies leave room for research on the relevance of $\mathrm{Al}$ Ghazali's educational thoughts on Islamic education for millennial children. It is at this point that this research takes its novelty. It is hoped that from this research, the relevance of Al-Ghazali's educational thoughts on Islamic education for children in this millennial era will be found.

The type of research used in this research is literature or library research. Therefore, in this research, the author used descriptive research with more emphasis on the strength of the analysis of data sources and existing data, by relying on existing concepts to be interpreted. ${ }^{19}$ The data sources and types of data used are primary data sources, in which the data were collected, processed and presented as the first source ${ }^{20}$ The data sources are the book of Al-Ghazali's Thoughts on Education by Abidin Ibn Rusn and the book of Islamic Education by Bukhari Umar. Secondary Data are data collected, processed and presented by other parties, usually in the form of publications or journals. $^{21}$ The data collection technique used was the documentation method. According to Suharsimi Arikunto, the definition of the documentation method is looking for data about variables or things in the form of transcripts of books, magazines, newspapers, notes, inscriptions, quick methods, and legends. ${ }^{22}$ This technique is used by the author in order to collect data contained in al-Ghazali's thoughts on education. The technique of data analysis is content analysis used in order to draw authentic conclusions from a book of al-Ghazali's thoughts $^{23}$. The procedures are by selecting the text you want to investigate, specifying the items, conducting research, and drawing conclusions. ${ }^{24}$

19 Soejono and Abdurahman, Metode Penelitian Suatu Pemikiran Dan Penerapannya (Jakarta: Rineka Cipta, 1999), 25. 1992), 76-80.

${ }^{20}$ Neong Muhadjir, Metodologi Penelitian Kualitatif (Yogyakarta: Rake Sarasin,

21 Moh. Nazir, Metode Penelitian (Jakarta: Ghalia Indonesia, 2003), 57.

${ }^{22}$ Suharsimi Arikunto, Prosedur Penelitian Suatu Pendekatan Praktek (Jakarta: Rineka Cipta, 2002), 234.

23 Muhammad Zainudin, Karomah Syaikh Abdul Qodir Al-Jailani (Yogyakarta: Pustaka Pesantren, 2004), 120.

24 Sutrisno Hadi, Metode Research I (Yogyakarta: Andi Offset, 1997), 42.Sutrisno Hadi, Metode Research I, (Yogyakarta: Andi Offset, 1997), h. 42 
The Relevance of Al-Ghazali's Thoughts on Islamic Education for Children in the Millennial Era

\section{The Purpose of Islamic Education}

The purpose of Islamic education is inseparable from the purpose of human creation in this universe by Allah SWT. The purpose of Islamic education is closely related to the purpose of human life in Islam, to create personal servants of Allah who always fear Him, and can achieve a happy life in this world and the hereafter. In the context of personal sociology, piety becomes rahmatan lil 'alamin, both on a small and large scale. The purpose of human life in this term can also be referred to as the ultimate goal of Islamic education. ${ }^{25}$ Education in the millennial era can be seen from the purpose of Islamic education in the millennial era which puts more emphasis on the goal of making humans as human beings who obey Allah's commands and stay away from all prohibitions because then humans will be safe in the world and the hereafter. So, the core of the goal of Islamic education in the millennial era is to make people who are obedient to God's commands.

Meanwhile, according to al-Ghazali, the purpose of education is to approach God by carrying out mandatory worship and sunnah worship, and the aim is also to realize the ability of humans to carry out worldly tasks well and to improve their quality through the knowledge they practice. The long-term educational goal is a self-approach to God. Education in the process must lead humans towards the introduction and then self-approach to the God who created nature. Humans draw closer to Allah by performing obligatory worship and sunnah worship. Therefore, the goal of Islamic education is beneficial in this world and the hereafter. On the other hand, the purpose of short-term Islamic education is to aim only at the world, such as being good in everything, as in work, profession, and others.

In conclusion, the purpose of Islamic education for children in the millennial era with the above objectives is still related. Both emphasize the purpose of getting closer to Allah and staying away from His prohibitions, so that the goals of Islamic education for children in the millennial era are relevant to the goals of Islamic education according to Al-Ghazali.

${ }^{25}$ Yusep Solihudien, Strategi Melesatkan Trio Raksasa Kecerdasan Anak (Jawa Timur: Qiara Media, 2020), 18. 


\section{Islamic Education Resources}

According to Hasan Langgulung, sources of Islamic education in the millennial era are the Al-Qur'an and As-Sunnah. ${ }^{26}$ Meanwhile, according to Sa'id Ismail Ali, the sources of Islamic education consist of 6 kinds: Al-Qur'an, As-Sunnah, Words of Friends (Shahabih Madhhab), Community/social benefit (mashalil almursalah), Tradition or people's customs ('uruf), and the experts' thoughts in Islam (ijtihad). From the opinions of the experts above, the writer can conclude that the sources of Islamic education are not only centered on one reference but also from other sources of Islamic education which are still in the context of Islamic education. So the sources of Islamic education for children in the millennial era are the Qur'an and As-Sunnah. Meanwhile, sources in Islamic education according to Al-Ghazali also come from the Qur'an and As-Sunnah. Here we can see that there is a relevance or link between Islamic education for children in the millennial era and education according to Al-Ghazali's thoughts.

\section{Islamic Education Method}

The Islamic education method used in the millennial era are: First, the Hiwar Qurani and Nabawi method. This method is suitable because the millennial generation tends to have a high curiosity due to easily accessible technological factors resulting in this generation being able to have a dialogue in one direction to achieve learning goals. Second, the method of parable education which equates something with something. The pedagogical goal in this method will bring the millennial generation to stimulate impressions and messages related to implied meanings and educate the mind to think logically and soundly, and this is in accordance with the nature of the millennial generation who usually think rationally. Third, education with the example. The millennial generation needs a rule model for them so that education with this example will be able to bring a good and effective impression to them. Fourth, education with training and practice. This method is very important because the nature of millennial does not only want to watch but also want to try so that this method will be very effective for them. Fifth, ibrah and mauizoh methoe. This method is a very risky method actually, because it seems to scare and only gives advice, but the point taken from this method is how millennials tend to be empty-

${ }^{26}$ Abuddin Nata, Sejarah Pendidikan Islam (Jakarta: PT. Raja Grafindo Persada, 2004), 64-67. 
hearted and psychologically they are easily touched, therefore this method must be delivered properly and perfectly. ${ }^{27}$

From various methods of Islamic education above, the writer can conclude that in using various methods of Islamic education, educators must pay attention to the functions of the method. From these functions, educators are able to provide direction and instructions in implementing these methods, so that educators are able to apply effective and efficient methods that are in accordance with their needs: being a good human with good morals who can also be useful for other humans, both in this worldly life and the hereafter.

Judging from the method of Islamic education according to AlGhazali, the teaching method is more devoted to teaching religious education for children. For this, he has exemplified a method of exemplary mentality for children, fostering character, and inculcating virtues in students. Teaching methods according to al-Ghazali can be divided into two parts, namely religious education and moral education. The method of religious education according to al-Ghazali in principle begins with memorization and understanding, then continues with belief and justification, after that the enforcement of the arguments and statements that strengthen the faith.

From the explanation above, there are different ways of delivering Islamic education methods, in which the Islamic education method in the millennial era is delivered in a varied way and follows the times. Meanwhile, the educational method according to Al-Ghazali is to follow al-Ghazali's principles, namely the delivery by memorization, understanding, and others. Although they differ in the way they are delivered, the objectives to be achieved between the two methods are the same. So the author can conclude that the educational method in the millennial era with the educational method according to al-Ghazali is relevant.

\section{Education Curriculum}

In terms of the educational curriculum, the educational curriculum in the millennial era is more divinity-oriented, humanoriented, and nature-oriented. Thus, the contents of the curriculum will discuss the nature of God, humans, and the universe. The curriculum in the millennial era or today's learning system requires children to be able

27 Zaini Miftah, "Warisan Metode Pendidikan Islam Untuk Generasi Millennial," Al Ulya: Jurnal Pendidikan Islam 4, no. 1 (April 15, 2019): 72-94, doi:10.36840/ulya.v4i1.212. 
to do everything, and the religious learning is still in small portion when viewed in general schools. In addition, the curriculum in the millennial era is officially regulated by the state or the Ministry of Education and Culture with a mutually agreed agreement. ${ }^{28}$

Meanwhile, according to al-Ghazali regarding the educational curriculum, the educational curriculum must be delivered in stages in accordance with the child's development and should not view children as adults in small forms. Thus, it brings up the formula of teaching methods that must be appropriate with the material conveyed to students. So actually Islam is the one that discusses the different stages of children development and growth, and their rights and needs at each stage because humans are one person who cannot and or should not be equated with other persons. The level of understanding, grasping power, memory of science, ability to carry out life tasks, differ from one person to another. Therefore, in relation to the curriculum, al-Ghazali based his thought that the educational curriculum must be prepared and then delivered to students in accordance with their psychological growth and development. Therefore, judging from the curriculum, there is no relevance or connection between the two.

From the various explanations above, it can be concluded that there is no maximum relevance between the Islamic education curriculum for children in the millennial era and the educational curriculum according to Al-Ghazali because Islamic education for children in the millennial era follows education based on the curriculum that has been issued by the government. The purpose of the curriculum is to develop the potential of students to become human beings who believe and fear God Almighty, to have noble character, healthy, knowledgeable, capable, creative, independent, and to become democratic and responsible citizens. While the educational curriculum according to al-Ghazali is to follow the principles of the curriculum that he has created, where education is more concerned with the level of intelligence of children and their age according to the child's mental readiness.

The results of this study show that the purpose of education in the millennial era is to get closer to God. It's similar with al-Ghazali's thoughts that the purpose of education is to perfect morals by doing God's commands and staying away from his prohibitions. Sources of education in the millennial era, namely the Koran and Hadith, are 
relevant to educational sources according to al-Ghazali. Between the methods of Islamic education in the millennial era and the methods of Islamic education according to al-Ghazali, there are differences in the methods of delivering Islamic education. The method of Islamic education in the millennial era is delivered in a varied way and follows the times while the educational method according to Al-Ghazali is to follow al-Ghazali's principles, namely the delivery by memorization, understanding, and others. Although they differ in the way they are delivered, the objectives to be achieved between the two methods are the same. So the author can conclude that the educational method in the millennial era with the educational method according to al-Ghazali is relevant. In term of curriculum, there is no maximum relevance between the educational curriculum in the millennial era and the educational curriculum according to Al-Ghazali because Islamic education for children in this millennial era follows education based on the curriculum that has been issued by the government, while the educational curriculum according to al-Ghazali follows the principles of the curriculum that he has made, in which his education pays more attention to the level of intelligence of the child and his age level according to the child's mental readiness.

From the description above, it can be concluded that al-Ghazali's thoughts on education have relevance to Islamic education for children in the current millennial era, but the relevance is not maximal. This can be seen from the compatibility between al-Ghazali's educational theory and education applied in the millennial era. However, there are theories that are still and have not been implemented, for example there are still differences in the educational curriculum so that the educational curriculum in the millennial era and the educational curriculum according to al-Ghazali are irrelevant.

\section{Conclusion}

Al-Ghazali's concept of thoughts about education is the process of humanizing humans from the time of their occurrence until the end of their lives through various knowledge delivered in the form of teaching in stages, where the teaching process is the responsibility of parents and society towards self-approach to God so that they become perfect humans. The purpose of education according to Al-Ghazali is a long-term goal that is getting closer to Allah, and the short-term goal that is the realization of human ability to carry out worldly tasks well. 
Islamic education for millennial children is education that uses rational knowledge that follows education based on the curriculum that has been issued by the government. The purpose of the curriculum is to develop the potential of students to become human beings who believe and fear God Almighty, have noble character, are healthy, knowledgeable, capable, creative, independent, and become democratic and responsible citizens.

Al-Ghazali's thoughts on education have relevance to Islamic education for children in the current millennial era, but the relevance is not maximal. This can be seen from the compatibility between alGhazali's educational theory and education applied in the millennial era. However, there are theories that are still and have not been implemented, for example there are still differences in the educational curriculum so that the educational curriculum in the millennial era and the educational curriculum according to al-Ghazali are irrelevant.

\section{Bibliography}

Adu, La. "Pandangan Imam Al-Ghazali Tentang Pendidikan Akhlak Di Lingkungan Keluarga." Horizon Pendidikan 10, no. 2 (January 9, 2019). https://www.jurnal.iainambon.ac.id/index.php/hp/article/view/707.

Alwizar. "Pemikiran Pendidikan Al-Ghazali." POTENSIA: Jurnal Kependidikan Islam 1, no. 1 (June 2, 2015): 129-49. doi:10.24014/potensia.v1i1.1245.

Arikunto, Suharsimi. Prosedur Penelitian Suatu Pendekatan Praktek. Jakarta: Rineka Cipta, 2002.

Darman, Flavianus. Undang-Undang Republik Indonesia Nomor 20 Tahun 2003 Tentang Sistem Pendidikan Nasional. Jakarta: Transmedia Pustaka, 2007.

Fadli, Adi. "Konsep Pendidikan Imam Al-Ghazali Dan Relevansinya Dalam Sistem Pendidikan Di Indonesia." El-Hikam 10, no. 2 (2017): 276-99.

H. M. Asyari. Konsep Pendidikan Islam Implementasinya Dalam Tradisi Klasik Dan Propogasi Modern. Jakarta: Rabbani Press, 2011.

Hadi, Sutrisno. Metode Research I. Yogyakarta: Andi Offset, 1997.

Kamalia, Nu'tih. "Konsep Ilmu Pendidikan Menurut Imam Al-Ghazali." At-Ta'dib 10, no. 1 (January 26, 2016). doi:10.21111/at-tadib.v10i1.335.

Miftah, Zaini. "Warisan Metode Pendidikan Islam Untuk Generasi Millennial." Al 
Ulya: Jurnal Pendidikan Islam 4, no. 1 (April 15, 2019): 72-94. doi:10.36840/ulya.v4i1.212.

Muhadjir, Neong. Metodologi Penelitian Kualitatif. Yogyakarta: Rake Sarasin, 1992.

Mukromin. "Pemikiran Imam Al-Ghazali Dalam Pendidikan Islam." PARAMUROBI: JURNAL PENDIDIKAN AGAMA ISLAM 2, no. 1 (October 5, 2019): 33-42. doi:10.32699/paramurobi.v2i1.814.

Musfioh, Imroh Atul. "Pemikiran Pendidikan Islam Perspektif al-Ghazali." SYAMIL: Jurnal Pendidikan Agama Islam (Journal of Islamic Education) 2, no. 1 (June 1, 2014): 14. doi:10.21093/sy.v2i1.493.

Muzakki, Jajang Aisyul. "Pemikiran Al-Ghazali Tentang Ganjaran Dan Hukuman Dalam Pendidikan Islam.” AWLADY: Jurnal Pendidikan Anak 3, no. 1 (February 28, 2017). doi:10.24235/awlady.v3i1.1253.

Nata, Abuddin. Sejarah Pendidikan Islam. Jakarta: PT. Raja Grafindo Persada, 2004.

Nazir, Moh. Metode Penelitian. Jakarta: Ghalia Indonesia, 2003.

Purwinto, Nanang. Pengantar Pendidikan. Yogyakarta: Graha Ilmu, 2014.

Rahmawati, Miya. "Mendidik Anak Usia Dini Dengan Berlandaskan Pemikiran Tokoh Islam Al-Ghazali." Al Fitrah: Journal of Early Childhood Islamic Education 2, no. 2 (January 1, 2019): 274-86. doi:10.29300/alfitrah.v2i2.2271.

Rohayati, Enok. "Pemikiran Al-Ghazali Tentang Pendidikan Akhlak." Ta'dib: Jurnal Pendidikan Islam 16, no. 01 (2011): 93-112. doi:10.19109/td.v16i01.56.

Soejono and Abdurahman. Metode Penelitian Suatu Pemikiran Dan Penerapannya. Jakarta: Rineka Cipta, 1999.

Solihudien, Yusep. Strategi Melesatkan Trio Raksasa Kecerdasan Anak. Jawa Timur: Qiara Media, 2020.

Suban, Alwan. "Konsep Pendidikan Islam Perspektif Al-Ghazali." Idaarah: Jurnal Manajemen Pendidikan 4, no. 1 (June 21, 2020): 87-99. doi:10.24252/idaarah.v4i1.13760.

Tambak, Syahraini. "Pemikiran Pendidikan Al-Ghazali." Al-Hikmah: Jurnal Agama Dan Ilmu Pengetahuan 8, no. 1 (2011): 73-87. 
116 | AJIS : Academic Journal of Islamic Studies, vol. 6, no. 1, 2021

Tirtarahardja, Umar, and La Sulo. Pengantar Pendidikan. Jakarta: PT Rineka Cipta, 2005.

Ulum, M. Miftahul. "Konsep Pendidikan Anak Menurut Al-Ghazali dan Relevansinya dengan Arah dan Tujuan Pendikan Nasional di Indonesia." At-Ta'dib 4, no. 2 (September 1, 2009). doi:10.21111/at-tadib.v4i2.592.

Umar, Bukhari. Ilmu Pendidikan Islam. Jakarta: Amzah, 2011.

Zainudin, Muhammad. Karomah Syaikh Abdul Qodir Al-Jailani. Yogyakarta: Pustaka Pesantren, 2004. 